
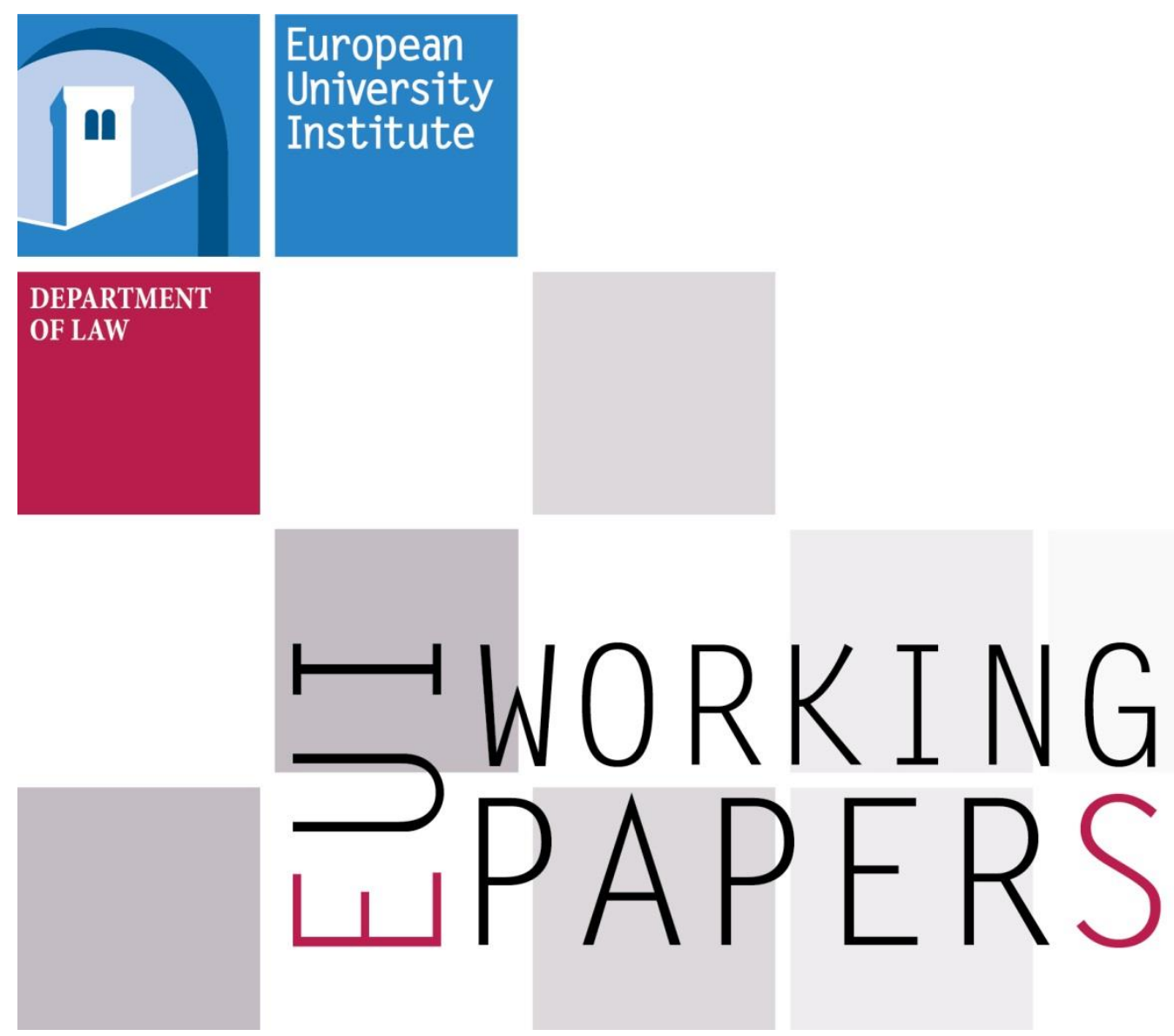

LAW 2016/22

Department of Law

After Brexit: Protecting European citizens and citizenship from fragmentation 

European University Institute Department of Law

\section{AfTER Brexit: Protecting European CitIZENS AND CITIZENSHIP FROM FRAGMENTATION}

Oliver Garner

EUI Working Paper LAW 2016/22 
This text may be downloaded for personal research purposes only. Any additional reproduction for other purposes, whether in hard copy or electronically, requires the consent of the author. If cited or quoted, reference should be made to the full name of the author, the title, the working paper or other series, the year, and the publisher.

ISSN 1725-6739

(C) Oliver Garner, 2016

Printed in Italy

European University Institute

Badia Fiesolana

I-50014 San Domenico di Fiesole (FI)

Italy

www.eui.eu

cadmus.eui.eu 
Author contact details

Oliver Garner

Ph.D. Researcher

Department of Law

European University Institute

Oliver.Garner@eui.eu 


\begin{abstract}
*
This paper takes the normative position that the fragmentation caused by the United Kingdom's withdrawal from the European Union requires legal solutions to protect the rights and status of EU citizens in the United Kingdom, and UK citizens in the European Union. The suitability of international law, domestic law, and European Union law measures are analysed on the basis of how comprehensive protection would be, and how practicable the solutions. The paper concludes with the observation that the upheaval of Brexit has prompted radical reconsideration of how the EU legal order and EU citizenship may develop in the future. Accordingly, constituting a core European citizenry would insulate European citizens and citizenship from fragmentation in the EU legal order.
\end{abstract}

\title{
Keywords
}

Brexit; EU citizenship; Core Europe; Fragmentation; Withdrawal

I would like to thank Marise Cremona, Hitesh Dhorijawala, Giuseppe Martinico, Kinanya Pijl, Martijn Van den Brink, Neil Walker, and the participants in the EUI EU Law Working Group meeting on 16 September 2016, the SSSUP-EUI Joint Doctoral Workshop of 23 September 2016, and the University of Edinburgh Europa Research Group seminar of 25 October 2016 for invaluable comments on earlier drafts of this paper. 


\section{Table of contents}

INTRODUCTION: A SEISMIC EVENT FOR EUROPEAN INTEGRATION................................ 1

THE BENEFITS OF EUROPEAN INTEGRATION FOR INDIVIDUALS: THE EXTENDED

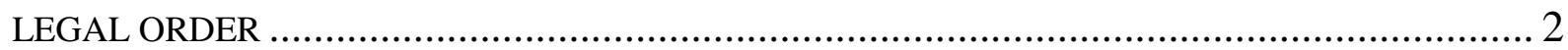

THE CONSEQUENCES OF FRAGMENTATION FOR INDIVIDUAL RIGHTS .................... 4

LEGAL SOLUTIONS TO PROTECT CITIZENS AND CITIZENSHIP ..................................... 7

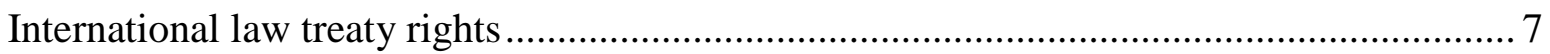

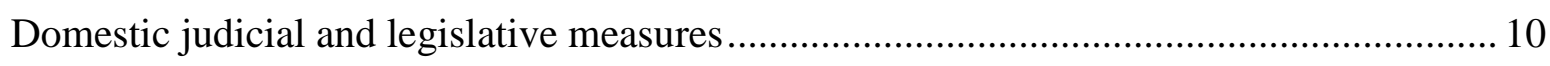

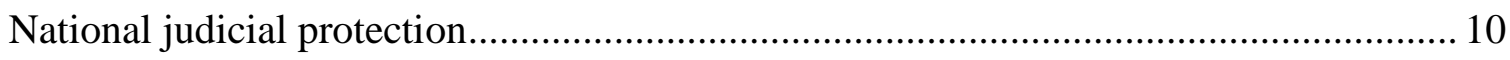

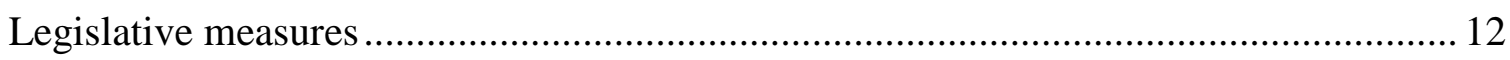

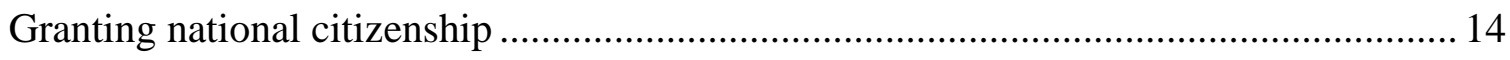

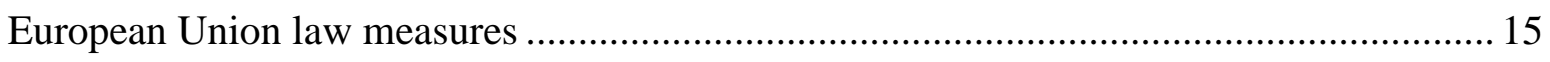

Judicial measures on the basis of Rottman .............................................................. 15

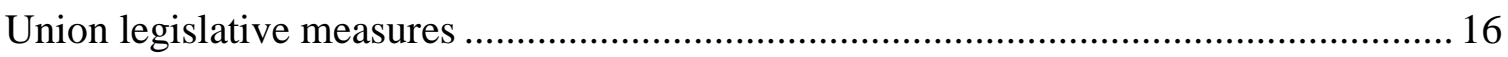

Primary law revision: Reform of citizenship of the European Union ............................ 19

CONCLUSION: A PHOENIX MOMENT FOR EUROPEAN INTEGRATION? .......................... 21 



\section{Introduction: A seismic event for European integration}

The decision of the United Kingdom population on 23 June 2016 to leave the European Union is of seismic significance. On the institutional level, the result of the referendum could lead to the first use of Article 50 TEU by a Member State to withdraw from the European Union. This is an unprecedented legal event that would challenge the forward motion of the European Union's deeper integration and wider territorial expansion. On the individual level, for the first time in the European Union's history a whole Member State polity could lose the rights that its members derive from the Union legal order, as well as the status of EU citizenship. Furthermore, EU citizens from other Member States would not be able to rely on EU law that may be fundamental to their life plans within the territory of the United Kingdom. This paper analyses this phenomenon, which it defines as fragmentation in the scope of European integration. Fragmentation manifests itself through Union law norms no longer being enforceable for Union citizens within the territory of a former Member State, and no longer being applicable to this state's citizens in the territory of the European Union. The normative argument is that the negative consequences for the coherence of the Union legal order, and therefore the benefits of that order for individuals, mean that legal solutions should be considered to insulate individuals from the full effects of fragmentation.

The first part of the paper will outline a brief conception of the Union legal order that details its benefits for European citizens. This enables an understanding of how these benefits would be affected in the event of Member State withdrawal. The second part will focus on the human aspect of integration in detailing the consequences of fragmentation for the rights of European citizens. The final part of the paper will then consider solutions that could maintain not only the positive force of the rights found in Union law for all affected individuals, but also the substance of the supranational status of EU citizenship for nationals of a former Member State. The conclusion is that the disconnection of EU citizenship from being predicated on Member State nationality, and the consequent constitution of a core European citizenry, would provide the most comprehensive insulation for EU citizens from national decisions to withdraw from the Union legal order. Although it seems that such a solution will be difficult to realise at the current stage of European integration, there are indications from the Union institutions that consideration of such developments is on the horizon. ${ }^{1}$ The fact that the Brexit vote has prompted such reassessment of the value of European integration and citizenship, and radical consideration of how this supranational status may develop in the future, means that the United Kingdom's withdrawal could prove to be a phoenix moment for European integration.

1 Charles Goerens, Amendment 882 to 'Possible evolutions of and adjustments to the current institutional set-up of the European Union', Motion for a resolution, Paragraph 37a: "Advocates to insert in the Treaties a European associate citizenship for those who feel and wish to be part of the European project but are nationals of a former Member State; offers these associate citizens the rights of freedom of movement and to reside on its territory as well as being represented in the Parliament through a vote in the European elections on the European lists; Emphasises that involving citizens in the political process of their country of residence helps to build European democracy, and therefore calls for the electoral rights of citizens residing in a Member State of which they are not nationals, as set out in Article 22 TFEU, to be extended to include all remaining elections: provincial, regional, and national". (European Parliament, 21 October 2016) <http://www.europarl.europa.eu/sides/getDoc.do?pubRef=-\%2f\%2fEP\%2f\%2fNONSGML $\% 2 \mathrm{bCOMPARL} \% 2 \mathrm{bPE}$ $-592.348 \% 2 \mathrm{~b} 01 \% 2 \mathrm{bDOC} \% 2 \mathrm{bPDF} \% 2 \mathrm{bV0} \% 2 \mathrm{f} \% 2 \mathrm{fEN}>$ accessed 9 November 2016. 


\section{The benefits of European integration for individuals: The extended legal order}

The benefits of European integration for individuals is the creation of a legal order which extends beyond national boundaries. ${ }^{2}$ This means that individuals can rely on the protection of positive law throughout the territory of the European Union when they engage in fundamental professional, social, and personal activities. Such activities as moving across the internal frontiers of the Union, taking up employment in a Member State, and establishing oneself in that Member State without any discrimination on the basis of nationality are protected. Therefore, these legal rights can be conceptualised as guarantees of the conditions for the pursuit of individual and collective fulfilment. Each Member State has a duty to guarantee these conditions for European citizens in their agreement to pursue ever closer union among the peoples of Europe. The extent of this protection for all European citizens is conditional on the exact nature of the obligations agreed upon in primary and secondary law within the areas of competence conferred upon the Union.

Despite the foundations of the Union as an international treaty regime, the individual European citizen has long been at the centre of deepening integration and the bearer of legal rights. This innovation did not arise through the explicit wording of the Treaties, but instead through the Court of Justice of the European Union's (CJEU) application of Union law. In the case of Van Gend en Loos, the Court outlined that Union law "intended to confer upon ... [individuals] rights which become part of their legal heritage". ${ }^{3}$ The consequence of this adjudicative integration is that primary and secondary Union law is created expressly, in addition to interstitial law 'made' by the Court, for the purpose of ensuring the fulfilment of European citizens. Furthermore, a sophisticated architecture has been established to make such norms enforceable in the legal orders of the Member States, ${ }^{4}$ in addition to being justiciable by national courts, ${ }^{5}$ and by the CJEU itself. ${ }^{6}$ The result of this has been the creation of a community space in which the citizens of the European Union can pursue life plans with the guarantee that they have a similarly extensive degree of promotion and protection of their legal rights as in their domestic legal orders. An explicit listing of the aspects that are to be guaranteed through the "creation of an area of freedom, security, and justice" can now be found in the Charter of Fundamental Rights of the European Union.

Arguably a key difference to national legal orders is that Union law does not crystallise customary community practice that already exists. ${ }^{8}$ Instead, the new European Union legal order seeks to create this community through extension of the conditions for fulfillment beyond the nation state in a manner in which individuals have not previously practiced. This represents the attempt to create a society

2 On the emancipatory benefits for individuals of such a legal order, see Floris De Witte, 'Emancipation through EU Law?' in Loïc Azoulai, Barbou des Places, and Etienne Pataut (eds.) Constructing the Person in EU Law: Rights, Roles, Identities (Hart Publishing 2016).

3 Case 26/63 Van Gend en Loos v Nederlandse Administratie der Belagstingen, ECR 1, para 3.

4 C-6/90 Francovich v Italy, [1991] ECR I-05357.

5 Consolidated Version of the Treaty on the Functioning of the European Union [2012] OJ C326/47 (herein cited as 'TFEU'), art 267.

6 Consolidated Version of the Treaty on European Union [2012] OJ C326/13 (herein cited as “TEU”), art 19.

7 Charter of Fundamental Rights of the European Union [2000] OJ C364/1.

8 From an analytical positivist perspective, see H.L.A Hart's account of the evolution of legal systems from primitive to sophisticated through the creation of secondary rules (H.L.A Hart, The Concept of Law ( $3^{\text {rd }}$ edn, Clarendon Law Series 2012); from a political theory perspective, see Hannah Arendt's account that when human beings come together a space is generated that changes over time, revealing itself in the private context as custom, in a social context as convention, and in a public context as laws, statutes, and constitutions. (Hannah Arendt and Jerome Kohn, The Promise of Politics (Schocken Books 2007). 
through law and the incentives enshrined in the protection of rights, rather than law being used to ensure the fulfilment of pre-existing community practices and standards. ${ }^{9}$ The nature of the Union legal order of rules preceding and incentivising practice as opposed to crystallising and ensuring pre-existing practice is relevant to understanding how fragmentation in this order can occur. If individuals do not sufficiently feel that they 'own' this legal system, that they do not regard it to be legitimate from the 'internal perspective' 10 as it does not reflect their social practices, then they are more likely to expose the underlying international treaty structure and reject the legal order through a majoritarian decision to withdraw. ${ }^{11}$

The creation of citizenship of the European Union in 1992 can be interpreted as an attempt to agglomerate this legal experiment into one holistic supranational status for European individuals. The supplementary nature of citizenship means that it is aspirational: rather than crystallising in law a preexisting community status, it seeks to create a new status. This currently operates as a limited supplement to national citizenship, but may be imbued with thicker substantive content in the future. ${ }^{12}$ This aspirational nature is evidenced by the Court of Justice's statements that Union citizenship is destined to be the fundamental status of all Member State nationals. ${ }^{13}$ What is of crucial importance with regard to the Brexit context is that the creation of supranational citizenship created a potentially disastrous tension between Member States as the interface through which citizens derived their Union law rights, and the roots of a direct connection between the Union and 'its' citizens such as is present in federal citizenship. $^{14}$

The United Kingdom referendum lit this fuse: for the first time a Member State may cease to operate as the interface between the European Union legal order and its citizens, thus severing the membership condition necessary for its nationals to be European Union citizens. In terms of Habermas' conception of the 'dual constituent subject' ${ }^{15}$ of the European Union - the same persons act as both members of a 'European people' and as 'citizens of the Union' - the withdrawal debate and its eventual enactment can be understood as a fundamental challenge to the compatibility of these two roles. ${ }^{16}$ Therefore, a key theme in this paper is whether it is possible not only to ensure that affected citizens retain the capacity to exercise their rights in the Union legal order, but also whether the status from which they derive these rights may also be protected. The underlying value of integration and the links created between the

9 Karlo Tuori provides a similar account from the perspective of the 'juridical' constitution: "What has detached European law from an ideal-typical state legal order is its fundamental policy orientation which has left its impact on constitutional law too... Such key principles of the juridical constitution as direct effect and supremacy were also motivated by policy considerations; by the effective and uniform application of European law which aimed at the establishment and functioning of the common market". (Emphasis in the original). Karlo Tuori, European Constitutionalism (Cambridge University Press 2015), 16.

10 H.L.A Hart, The Concept of Law ( $3^{\text {rd }}$ edn, Clarendon Law Series 2012), 56.

11 This is a legal theoretical perspective utilising H.L.A Harts's concept of law; from the perspective of constitutionalism the famous 'no demos thesis' expresses a similar idea: see Dieter Grimm, 'Does Europe Need a Constitution?' (1995) ELJ 1.

12 TFEU art.25 provides the legal competence for adopting "provisions to strengthen or to add to the rights listed".

13 Case C-184/99 Rudy Grzelczyck v Centre Public d'aide sociale d'Ottignies-Louvain-la-Neuve [2001] ECR I-06192, para 31.

14 See Francesca Strumia, 'Brexiting European Citizenship Through the Voice of Others', (2016)17 GLJ Brexit supplement 109, 113 : "If European citizenship were a real federal citizenship, it would entail a direct link between the Union and its citizens, with which the Member States would not be able to interfere."

15 Jürgen Habermas, 'The Crisis of the European Union in Light of a Constitutionalization of International Law - An Essay on the Constitution for Europe' in The Crisis of the European Union: A Response (Polity 2013), 35: "Citizens are involved in a twofold manner in constituting the higher-level political community - directly in their rule as future EU citizens and indirectly in their role as members of one of the national peoples" 35.

16 The balance between ensuring the fulfilment of individuals in their capacity as Member State nationals and in their capacity as European Union citizens is a key aspect in understanding and justifying withdrawal; I intend to return to this in later work. 
individual and the Union legal order beyond their Member State must be borne in mind when considering solutions to the problems of withdrawal.

To summarise, the benefits of European integration for individuals is the creation of a legal order which extends beyond the territory of the nation in which one is currently present. The additional benefit of citizenship in this transnational legal construct is that it gathers all these disparate legal benefits together under one overarching legal status. This provides a clearly defined ${ }^{17}$ residual category ${ }^{18}$ of exactly who Union law is applicable to and therefore who is eligible to benefit from its guarantees. If this legal order functions in an internally coherent and holistically harmonious manner ${ }^{19}$ then positive law is created which provides enforceable guarantees for individuals. They can rely on this law to pursue their particular life plans throughout the community space of the Union's territory, regardless of which nation they are currently physically present in.

In contrast, if the law of the Union is not internally coherent nor holistically harmonious, then individuals will not be able to rely on the law to a satisfactory degree in order to pursue their life activities. Thus, the legal order and its consequent benefits for individuals are fragmented. Such fragmentation can occur as a result of unauthorised violations of Union law, such as when a Member State fails to implement a Directive,$^{20}$ or can occur as a result of constitutionally authorised derogations in the form of the opt-outs from entire sectors of the legal order created through revision of the primary law in the Treaties. ${ }^{21}$ Regardless of how the phenomenon arises, the key feature of fragmentation is that affected individuals are not able to rely on the enforcement of a Union law norm which they would have been able to if the legal order were functioning in a coherent and harmonious manner. The complete withdrawal of a Member State therefore represents the most extreme instance of this fragmentation through the complete de-application of all the norms of the Union legal order in the territory of the withdrawing state and to its nationals. This is fragmentation in the scope of the Union legal order.

\section{The consequences of fragmentation for individual rights}

As an initial survey of the positive law rights that citizens will lose through withdrawal, the affected citizens can be divided into three categories: (1) citizens who have settled either permanently or semipermanently in another Member State; (2) citizens who are mobile across Europe without settling; ${ }^{22}$ and (3) citizens of the withdrawing Member State who are sedentary within their nation. As an initial point, the de-application of the Treaties in the withdrawing Member States means that its citizens will lose their status as EU citizens and therefore their right to move and reside freely within the territory of the Member States, ${ }^{23}$ the electoral rights to vote and stand as candidates in European Parliament and municipal elections in their Member State of residence, ${ }^{24}$ the diplomatic right of protection of consular

17 'Every person holding the nationality of a Member State': TFEU, art.20.

18 Residual, or default, because primary and secondary law can specifically define sub-categories of individuals that norms apply to both within the category of EU citizens (for example 'workers' as defined in Regulation 492/2011) and outside of the category ('Third Country Nationals' (TCNs) as defined by TFEU art.79).

19 These concepts refer to law being created and enforced in a coherent manner within certain sectors or chapters of the acquis (internal coherence) and also to these different sectors being harmonious between each other (holistic harmony).

20 See inter alia C-6/90 Francovich v Italy, [1991] ECR I-05357.

21 For example, see TFEU Protocol No (21) detailing the United Kingdom and the Republic of Ireland's 'flexible' opt-outs from Area of Freedom, Security, and Justice measures, and Protocol No (22) for Denmark's rigid opt-out. I conceptualise such derogations as fragmentation in the depth of the Union legal order.

22 The distinction between these two categories roughly corresponds to the Citizens Directive's differentiation of rights for EU citizens present for more than three months (Category (1)) and those present for less than three months (Category (2)) in the territory of another Member State.

23 TFEU, art 20(a).

24 TFEU, art 20(b). 
authorities of any Member State in a third country, ${ }^{25}$ and the administrative right to petition the institutions in any of the Treaty languages and obtain a reply in the same language. ${ }^{26} 27$

Within the first category of citizens, those with the status of 'worker' will no longer be protected by Article 45 TFEU ensuring free movement, the abolition of discrimination, and the right to remain on the territory of a Member State. Furthermore, the provisions of the Citizens Directive, ${ }^{28}$ including Article 7 granting a right of residence for more than 3 months, ${ }^{29}$ will be de-applied in addition to Regulation 492/2011, including Article 1 on the right to take up an activity as an employed person with the same priority as nationals of the state, ${ }^{30}$ and Article 7 on the right not to be treated differently from national workers and to have the right to the same social and tax advantages. ${ }^{31}$ Citizens who wish to settle permanently in another Member State who are not workers would lose the conditional EU citizenship right in Article 21 TFEU to move and reside freely within the Member States. ${ }^{32}$ For those who have decided to settle in another Member State to retire, Article 7 of the 2004 Directive granting a right to reside for more than 3 months provided they have sufficient resources to not become a burden on the social system would be no longer applicable. ${ }^{33}$ Students whose stay is conditional on pursuing a course of study at either a private or public institution ${ }^{34}$ would also no longer be apply to rely on this provision of secondary law. For each of these categories, the repatriation of residence jurisdiction by the withdrawing Member State with regard to EU citizens, and by other Member States with regard to the withdrawing state's citizens, ${ }^{35}$ could mean that affected individuals would have to apply for visas to remain.

The second category - mobile citizens who do not wish to settle permanently in another Member State - would also be deprived of the Article 21 TFEU right to move and reside freely. Although this right is defined as "subject to the limitations and conditions laid down in the Treaties and by the measures adopted to give them effect", ${ }^{36}$ the significance is the shift from the presumption of free movement

25 TFEU, art 20(c).

26 TFEU, art 20(d).

27 In 'Pretending There is No Union: Non-derivative Quasi-Citizenship Rights of Third Country Nationals in the EU' in Daniel Thym and Margarite Zoeteweij-Turhan (eds), Rights of Third Country Nationals under EU Association Agreements (Brill Nijhoff 2015), Dimitry Kochenov and Martijn van den Brink argue that these administrative rights can be enjoyed by 'any person' due to their duplication in the broader context of Article 227 and 228 TFEU. The authors conclude that "it is puzzling why the rights to petition the EP and to apply to the Ombudsman are actually included among the citizenship rights of the Treaty". Although it is true that the text of Article 24 TFEU mirrors these provisions, the key added benefit seems to be that every citizen may write and receive a reply in one of the language outlined in Article 55(1) TEU: this citizenship right could therefore be regarded as a right to linguistic diversity. Consequently, although an ex EU-citizen may well retain the right of petition due to their status as "any natural or legal person residing...in a Member State" for the purposes of Article 227 and 228, if their language is removed from Article 55 then the right that is lost is what language they are able to use.

28 Directive 2004/38/EC of the European Parliament and of the Council of 29 April 2004 on the rights of citizens of the Union and their family members to move and reside freely within the territory of the Member States [2004] OJ L158/77 (herein referenced as 'Directive 2004/38').

29 Directive 2004/38, art 7(1)(a).

30 Regulation (EU) No 482/11 of the European Parliament and of the Council of 5 April 2011 on freedom of movement for workers within the Union Text with EEA relevance [2011] OJ L141/1 (herein referred to as Regulation 492/2011), art 1(1), (2).

31 Regulation 492/2011, art 7(1),(2).

32 TFEU, art 21(1).

33 Directive 2004/38, art 7(1)(b).

34 Directive 2004/38, art 7(1)(c).

35 Although it should be noted that Member States will be subject to legislation regarding the residence rights of Third Country Nationals under Article 79 TFEU (see discussion on page 23 below).

36 TFEU, art 21(1). 
which is to be rebutted by the Treaty provisions to the starting point of allowing the nation states to define the conditions of movement internally. The de-application of the Schengen acquis now contained within Regulation 562/2006 would have the same consequence, particularly the right in Article 20 which states that "[i]nternal borders may be crossed at any point without a border check on persons, irrespective of their nationality, being carried out". ${ }^{37}{ }^{38}$ Furthermore, the right to exit ${ }^{39}$ and enter ${ }^{40}$ Member States and to reside for up to 3 months ${ }^{41}$ without any conditions or formalities other than an identity card or passport contained in the 2004 Directive would be de-applied. Further to the restrictions on the right to move and reside, the de-application of Union law would also affect the convenience of using services while moving through Europe. ${ }^{42}$

The final category is those citizens within the withdrawing Member State who do not exercise their rights to move and reside throughout the territory of the Union. The social rights that have been enshrined in EU law have been referred to as the 'social constitution'. ${ }^{43}$ This is indicative of the role ${ }^{44}$ of Union rights in supplementing and bolstering the traditional role of the constitutional state in guaranteeing the conditions for freedom and fulfilment of its citizens. ${ }^{45}$ It is important to note that rights which are contained in Directives have been implemented into the national legal orders of the Member State through domestic legislation. The key point, however, is that the Member State would no longer be under an obligation to implement secondary Union law. Therefore, it would be the prerogative of the legislature whether to retain, amend, or repeal such legislation. Regardless of the retention of the substance of these rights, the de-application of Article 19 TEU, Article 267 TFEU and Article 263 TFEU and Article 47 of the Charter of Fundamental Rights means that the Member State's citizens would no longer have recourse to judicial procedures at the supranational level to vindicate their rights.

Examples of the rights which would be de-applied in the event of withdrawal include the Directives on Maternity Leave and Parental Leave ${ }^{46}$ granting the right to parental leave for at least a period of four months. ${ }^{47}$ A further example is Directive 2003/88/EC concerning certain aspects of the organisation of working time ${ }^{48}$ which provides limitations on working hours, daily and weekly rest periods, and the provision of paid annual leave. In terms of the pursuit and guaranteeing of fulfilment of sedentary citizens, the important point here is that these are not rights which require the structure of the harmonised and extended Union legal order due to the fact they are not predicated on pursuing a life-plan outside

37 Regulation (EC) No 562/2006 of the European Parliament and of the Council of 15 March 2006 establishing a Community Code on the rules governing the movement of persons across borders (Schengen Borders Code)[2006] OJ L105/1, art 20.

38 The United Kingdom already has an opt-out from the Schengen acquis, and therefore the legal situation for EU citizens in the United Kingdom will remain the same.

39 Directive 2004/38, art 4.

40 Directive 2004/38, art 5.

41 Directive 2004/38, art 6.

42 For example, the new right not to be subjected to roaming charges found in Regulation (EU) 2015/2120 of the European Parliament and of the Council of 25 November 2015 laying down measures concerning open internet access [2015] OJ L310/1.

43 Claire Kilpatrick, 'Are the Bailouts Immune to EU Social Challenge Because They Are Not EU Law?' (2014) 10 European Constitutional Law Review (EuConst) 393, 394. See also Chapter 7 of Tuori, 'European Constitutionalism' (n.9).

44 This is not to say that the European Union has always necessarily fulfilled this role. See Karlo Tuori's discussion referenced in the footnote above.

45 Habermas, 'The Crisis of the European Union' (n.15).

46 Council Directive 2010/18/EU of 8 March 2010 implementing the revised Framework Agreement on parental leave [2010] OJ L68/13.

47 ibid, Clause 2.

48 Directive 2003/88/EC of the European Parliament and of the Council of 4 November 2003 concerning certain aspects of the organisation of working time [2003] OJ L299/9. 
the Member State borders ${ }^{49}$ However, they are rights in which the Union has either provided impetus for vindication, or has provided a minimum standard of compliance that a Member State cannot deviate from with judicial redress available to individuals if violated. This has therefore provided legal guarantees for the pursuit of fulfilment for European citizens within their own Member States.

This preliminary outline of the legal consequences of de-integration of a Member State's legal order from Union law has sought to show that the implications for European citizens of pure withdrawal are that it will be more difficult for the withdrawing state's citizens to move freely through the territory of the Union and to establish themselves in the societies of the other Member States. Concurrently, the same difficulties will be encountered by Union citizens seeking to establish themselves in the society of the withdrawn state. Furthermore, even for those citizens of the ex-Member State who do not wish to establish themselves in other Member States, the de-application of Union law could make the already established conditions for social life more difficult to vindicate. Due to the latter situation being purely internal after a withdrawal, and therefore outside the remit of the Union's action, it would be the responsibility of domestic political processes to ensure that these guarantees are preserved in the event of the de-application of Union law. The following section will, alternatively, consider the legal solutions that could ensure that the rights of EU citizens in the United Kingdom, and UK citizens in the European Union's territory, are preserved.

\section{Legal solutions to protect citizens and citizenship}

There are a range of potential options for protecting the rights of UK citizens in Europe and EU citizens in the UK. The tentative solutions proposed here are categorised by their source: international law, domestic law, and European Union law. In assessing the different solutions, I will utilise two standards of assessment: how comprehensive the protection afforded to citizens and citizenship will be; and how likely it is that the solution will be realised in the current political context of the European Union. These categorisations do not mean that the solutions are mutually exclusive; instead, the most practicable solutions may be utilised as a stop-gap measure which can then be developed in the future.

\section{International law treaty rights}

Seemingly the clearest and most practicable way in which individual rights could be protected is through the terms of a withdrawal treaty and any future relations treaty between the UK and the EU. Article 50 makes provisions for this: the primary condition for the Union's treaties to be de-applied in the withdrawing state is the conclusion of a withdrawal treaty "taking account of the framework for its (the withdrawing Member State's) future relationship with the Union". ${ }^{50}$ Maintaining the substantive benefits of Union law for citizens would not be limited to the terms of such a withdrawal treaty because the withdrawing state and the Union would be free to conclude international treaties creating positive rights for individuals. Sir David Edward and Derrick Wyatt have argued that the United Kingdom and the European Union may even be obliged to conclude a separate "future relations treaty" to enact the framework of the future relationship outlined in the withdrawal treaty. ${ }^{51}$ The advantage for affected individuals of this solution is the potential for creation of treaty rights that are binding in international law upon states. Crucially, however, regardless of how extensive rights protection is, international law cannot replicate the unique benefits of EU citizenship for UK citizens. Furthermore, the apparent

49 From the perspective of the United Kingdom's legal order, see the statements by the High Court that such rights fall into the category of 'rights capable of replication in the law of the United Kingdom'. R(Miller) v. Secretary of State for Exiting the European Union [2016] EWHC 2768 (Admin), [58].

50 TEU, art 50(2); if an agreement is not concluded the secondary condition for withdrawal is the end of the two year period after the notification to trigger Article 50 .

51 House of Lords European Union Committee, The Process of Withdrawing from the European Union (2015-2016, HL 11), para 24. 
political necessity of reciprocity of obligations between the Union and the United Kingdom would seem to be a grave practical impediment to the creation of a comprehensive rights protection scheme.

In negotiating a treaty, the Members of the European Parliament could have an important role to play in protecting the rights of the citizens that they represent. This is important due to the institution's role of representing European individuals in their constituent role as citizens of the Union. Article 50(2) outlines that the withdrawal agreement can be concluded only after obtaining the consent of the European Parliament. MEPs could withhold this consent until the framework for future relations provides what they regard as adequate protection for their constituents. Perhaps for precisely this reason Article 50(3) only bars the United Kingdom's members of the Council and the European Council from the negotiations on the side of the Union instead of also barring the United Kingdom's MEPs from the vote.

If an association agreement were chosen as the form for enacting a future relations treaty, then Article 218(6)(a)(i) outlines that the European Parliament's consent would be necessary. However, if such an association agreement were concluded after the withdrawal treaty came into force then the United Kingdom's MEPs would not have input into the agreement's content. Instead, the only representation for UK citizens would be from the negotiators on the UK side. For this reason, it is important that MEPs engage extensively and reflect their constituent's views in the creation of the framework for future relations that will be set out in the withdrawal treaty. Such a tailored association agreement could grant positive legal rights enforceable in international law for UK citizens and for EU citizens in the United Kingdom. Indeed, if the Court of Justice were to find that certain provisions of a treaty had direct effect, as they did in the association agreement with Poland,${ }^{52}$ then UK citizens could seek to enforce the terms of the treaty against the EU institutions or a Member State before the Court of Justice of the European Union. ${ }^{53}$ However, the very different context of the Europe Agreement must be borne in mind when considering how the Court of Justice would determine its jurisdiction. Whereas in the Polish context the agreement served as a stepping stone to accession, in the United Kingdom context it would serve the opposite purpose as a stepping stone away from membership. ${ }^{54}$

An 'off the shelf' treaty option for ensuring the free movement rights of citizens would be for the United Kingdom to become a party to the European Economic Area (EEA) agreement as a third country. Chapters I and II of Part III of the agreement ensure that both EU citizens and citizens of European Free Trade Area (EFTA) countries have the right to accept offers of employment ${ }^{55}$ move freely ${ }^{56}$ and stay for the purpose of this employment, ${ }^{57}$ and to establish themselves ${ }^{58}$ throughout the EU and EFTA Member States with the necessary social protections. ${ }^{59}$ These provisions mirror the rights granted to the citizenship sub-category of 'workers' in Article 45 TFEU. Furthermore, the EEA agreement makes provision for a court of justice (EFTA court) and an EFTA Surveillance Authority to ensure fulfilment of these obligations. ${ }^{60}$ The effect of the United Kingdom joining the EEA agreement for UK citizens within the sub-category of 'worker' would be the de facto retention of important rights that they have

52 Europe Agreement establishing a relationship between the European Communities and their Member States, of the one part, and the Republic of Poland, of the other part, concluded and approved on behalf of the Community by Decision 93/743/Euratom, ECSC, EC of the Council and of the Commission of 13 December 1993 (OJ 1993 L 348/1), art 37(1).

53 See Case C-162/00 Pokrzeptowicz-Meyer [2002] ECR I-01049.

54 For more on how political context influences the Court of Justice's interpretation of association agreements, see Christa Tobler, 'Context Related Interpretation of Association Agreements" in Daniel Thym and Margarite Zoeteweij-Turhan (eds.) Rights of Third Country National under EU Association Agreements (Brill Nijhoff 2015).

55 Agreement on the European Economic Area (OJ 1994 L 1/3) (herein referred to as the "EEA Agreement"), art 28(a).

56 EEA Agreement, art 28(b).

57 EEA Agreement, art 28(c).

58 EEA Agreement, art 31.

59 EEA Agreement, art 29.

60 EEA Agreement, art 108. 
been able to exercise through European Union law, and the concordant retention of such rights for EU citizens in the territory of the United Kingdom.

However, there are problems with the treaty solution from the perspective of providing holistic protection for UK citizens in the Union's territory. Treaty rights necessarily can only provide a piecemeal solution by enshrining the protection of individual rights in positive international law; it is not possible to preserve entirely the status of EU citizenship from which UK citizens derived these rights. Crucially, even the apparently readymade solution of the EEA agreement would not allow UK nationals to retain the substance of their EU citizenship. As a caveat to the implementation of the Citizens Directive by the EFTA states, the contracting parties to the EEA agreement declared explicitly that "[t]he concept of Union citizenship...has no equivalent in the EEA Agreement". ${ }^{61}$ Despite this, the EFTA Court ${ }^{62}$ has engaged in some creative interpretation in order to protect the rights of applicants in factual situations analogous to the Court of Justice's case law which relies on citizenship. ${ }^{63}$ Nevertheless, the crux of this legal position is that UK nationals will not retain the ostensibly unconditional Article 20 right to move freely and reside in the Member States if the United Kingdom accedes to the European Economic Area agreement.

The institutional effects of a treaty arrangement which does not preserve Union citizenship is that UK citizens will have no direct input into the process of how future Union law is created, beyond their representation by UK MEPs in the drafting of the withdrawal treaty. Following withdrawal, UK citizens will no longer be represented by their national ministers in the legislative institutions of the Council ${ }^{64}$ or by directly elected Members of the European Parliament. Furthermore, with the exception of the Court of Justice finding that certain treaty provisions have direct effect, UK citizens would also be disconnected from the supranational judicial architecture which provides for effective protection and enforcement of their rights. Therefore, an association agreement or similar treaty could protect the substance of citizens' rights at a particular moment, but it would not allow UK citizens to be involved in the progressive development of the content and enforcement of such rights.

Furthermore, in terms of practical feasibility, a serious and potentially fatal problem for treaty arrangements to protect individual citizens' rights comprehensively is reciprocity. If UK citizens are to be granted free movement, residence, and establishment rights on Union territory then it seems highly likely that the Union would demand that the United Kingdom grants reciprocal rights on these "nonnegotiable' issues to EU citizens in the territory of the United Kingdom. Such reciprocity could even be made a condition of the agreement. ${ }^{65}$ The political situation in the United Kingdom regarding the Brexit negotiations suggests that it is highly unlikely that the United Kingdom government will agree to legal obligations to vindicate extensively the pre-existing rights of EU citizens. The EEA option would require the United Kingdom to give full access to its territory to EU citizens who fulfill the conditions of the agreement; however this seriously contradicts the promises of the leave campaigners that the United Kingdom would be able to "take back control" of its borders. ${ }^{66}$ Furthermore, the sophisticated judicial oversight by the EFTA court contradicts the calls of leave campaigners to remove the United Kingdom

61 "Joint declaration by the contracting parties to decision no. 158/2007 incorporating Directive 2004/38/EC into the EEA Agreement".

62 See Case E-26/13, Gunnarsson, advisory opinion of 27 June 2014; for extensive discussion see Fredriksen and Franklin, 'Of Pragmatism and Principles: The EEA Agreement 20 Years On' (2015) 52 Common Market Law Review 629, 638-646.

63 For example, Case C-34/09 Ruiz Zambrano v Office national de l'emploi [2011] ECR I-01177.

64 On Habermas' account (see n.15 above) the Council is the institution that represents UK nationals in their role as members of a 'European people', whereas, as outlined above, the European Parliament represents individuals in their role as 'citizens of the Union'.

65 I thank Marise Cremona for clarification on the issue of reciprocity.

66 Macer Hill, 'Boris Johnson urges Brexit to "take back control"' (The Express, 20 Jun 2016) < http://www.express.co.uk/news/politics/681706/Boris-Johnson-vote-Brexit-take-back-control> accessed 27 August 2016. 
from the jurisdiction of 'foreign' courts. ${ }^{67}$ As an additional barrier, it is not even certain that the United Kingdom would be able to rejoin the European Free Trade Area (EFTA); the consent of all $31 \mathrm{EU}$ and EFTA Member States would be required, and Norway has already expressed misgivings about the move ${ }^{68}$ Even if the tailored option of a future relations treaty/association agreement were pursued, actors on the European Union side have made it clear that a non-negotiable condition of access to the free market would be granting free movement rights to EU citizens.

A potential compromise is the proposal of a migration 'emergency brake' for the United Kingdom of up to 7 years similar to the terms of the abortive Decision regarding a New Settlement for the United Kingdom. ${ }^{69}$ However, such a 'solution' can only be regarded as kicking the can further down the road: eventually the United Kingdom would need to grant full access to eligible EU citizens. This would be in direct contradiction to the promises of the referendum campaign to take back control over immigration policy. For Union citizens, such an emergency brake would be a substantive barrier for an extended duration of time to those who wish to exercise their free movement rights to enter the territory of the United Kingdom. Therefore, the apparent impasse between the United Kingdom government's position on immigration and the European Union's insistence on a non-negotiable core of reciprocity means that it is salient to consider whether domestic measures could provide a more desirable and practicable solution.

\section{Domestic judicial and legislative measures}

Potential domestic measures range from the protection of 'acquired rights' by national judiciaries without the need for legislation, to the specific promulgation or amendment of legislation to protect the integration rights of individuals, to the granting of national citizenship to affected UK and EU citizens. The benefits of such measures are that they can be more easily enforced by individuals in their country of residence through recourse to national administrative or judicial procedures. The disadvantage, however, is that national measures will only be applicable in the country of promulgation rather than providing for harmonised EU-wide measures. Even in the case of a UK citizen being granted the citizenship of a Member State and thus re-establishing themselves as an EU citizen, there is no guarantee of a holistic solution for all citizens because of the fluctuations between citizenship law in European countries, and the differing levels of receptiveness to such nationality fast-tracking.

\section{National judicial protection}

The UK's European Union Committee has considered whether the doctrine of 'acquired rights' could protect citizens. However the doctrine's operation is ambiguous. This is recognised through the statement that "there is no single definition of acquired rights under international law; broadly they are rights vested in individuals or companies which may withstand changes in the sovereignty or laws of a State" ${ }^{70}$ Despite this ambiguity, the language of the report conceives of protecting acquired rights as a

67 Michael Gove, 'EU Referendum: Michael Gove explains why Britain should leave the EU' (The Telegraph, 20 February 2016) < http://www.telegraph.co.uk/news/newstopics/eureferendum/12166345/European-referendum-Michael-Goveexplains-why-Britain-should-leave-the-EU.html> accessed 27 August 2016.

68 Patrick Wintour, 'Norway may block UK return to European Free Trade Association' (The Guardian, 9 August 2016) <https://www.theguardian.com/world/2016/aug/09/norway-may-block-uk-return-to-european-free-trade-association> accessed 27 August 2016.

69 Toby Helm, 'Brexit: EU considers migration 'emergency brake' for UK for up to seven years' (The Guardian, 24 July 2016) < https://www.theguardian.com/world/2016/jul/24/brexit-deal-free-movement-exemption-sevenyears?utm_source=esp\&utm_medium $=$ Email\&utm_campaign=GU+Today + main $+N E W+H+$ categories\&utm_term $=1830$ 50\&subid=17932543\&CMP=EMCNEWEML6619I2> accessed 27 August 2016.

70 EU Select Committee, The Process of Withdrawing from the European Union (n.49), 9, footnote 33. 
process of "deciding which rights would qualify"; ${ }^{71}$ this suggests a legislative choice on the part of either the Member States or the Union, rather than a legal doctrine which exists irrespective of such action. The discussion of this point by the expert witness Professor Derrick Wyatt QC indicates that a government could choose to "recognise" such rights. His further statement that "[m]y guess is that the inclination of Government and Parliament would be to be generous as regards those who already made their lives in the UK" suggests further that this is an administrative choice for national actors rather than an obligation that may be binding on nations, for example, through customary international law.

One possible avenue by which EU citizens in the United Kingdom ${ }^{72}$ could claim vindication of their, inter alia, acquired rights to remain and of residence without the need for recognition by the Government or Parliament could be through the English administrative law doctrine of substantive legitimate expectations. Applicants can claim the remedy of certiorari to quash a decision which frustrates a legitimate expectation; the courts could also issue a mandamus (mandatory order) to compel the public body to uphold the substantive rights of the applicant. Appositely to the possible implications of Brexit, the route towards recognition that the procedural right of judicial review may well place the government under an obligation to provide a substantive benefit was forged in a case dealing with the residence right of foreign nationals. ${ }^{73}$

The recognition of substantive legitimate expectations as a ground of judicial review in Coughlan ${ }^{74}$ provided a categorical approach to the doctrine of legitimate expectations. ${ }^{75}$ On the facts of the case, a representation by a local authority to a resident in a care-home that she would have a home for life fell under the third category of a substantive legitimate expectation arising from a promise. The subjects of this category are likely only to be a single person or a small number of people; therefore this seems unlikely to cover the case of a change of Government policy following withdrawal from the European Union. It is only likely that an individual could claim such a violation if they had been given reassurances by a particular administrative body or representative that their rights would not be affected. A possible example of this could be if Sadiq Khan, the Mayor of London, were to convert his rhetorical declaration that he will protect EU citizens in the United Kingdom ${ }^{76}$ into actual representations to citizens of their rights to remain and reside which are then frustrated. This could be particularly salient because the Mayor does not have competence over immigration policy.

The case of EU citizens being deprived of their rights to remain and reside falls more easily under the first category of the claim of a substantive legitimate expectation arising from a change of policy. ${ }^{77} \mathrm{In}$ contrast to the third category, the ambit of the first category is usually a sizeable part of the population: the "macro-political field". ${ }^{78}$ Laws LJ outlines that the more the decision challenged lies in this field,

71 ibid, para 26 (emphasis added).

72 I must admit that this consideration is limited to the case of EU citizens within the United Kingdom due to my unfamiliarity with the administrative law of the 27 other Member States, and whether any analogue to legitimate expectations could exist for UK citizens. This reveals the complexity of relying on national law for UK citizens who may be resident in any of the other 27 Member States.

73 Schmidt v. Secretary of State for Home Affairs [1968] CA 19, [1969] 2 WLR 337.

74 R. v North and East Devon Health Authority, ex parte Coughlan [2001] QB 213, [2000] 2 WLR 622, [57].

75 In category (a) the court may decide the public authority is only required to bear in mind its previous policy before changing course; in category (b) the court may decide that the promise or practice incudes a legitimate expectation of a particular procedure; and in category (c) the court can find an abuse of power when a lawful promise or practice has induced a legitimate expectation of a benefit which is substantive.

76 Jonn Elledge, 'London Mayor Sadiq Khan to EU Citizens: "You Are Welcome Here", (CityMetric, 24 June 2016) <http://www.citymetric.com/politics/london-mayor-sadiq-khan-eu-citizens-you-are-welcome-here-2201> accessed 27 August 2016.

77 R. v North and East Devon Health Authority, ex parte Coughlan [2001] QB 213, [2000] 2 WLR 622, [57].

$78 R$ v. Secretary of State for Education and Employment, ex parte Begbie [2000] 1 WLR 1115 (AC) 1131 (Laws LJ). 
the less intrusive the court's supervision will be. ${ }^{79}$ In accordance with the obiter dicta in Coughlan, therefore, the government would only be required to bear in mind its previous policy as a result of its Treaty obligations before deciding to change its policy towards the rights of residence of EU citizens. Individually affected citizens can only challenge this case on the grounds of 'Wednesbury unreasonableness', namely if the decision of the Government were so irrational than no rational public body would pursue it. ${ }^{80}$ An example of this could be a policy of instantaneous deportation of any EU citizens that previously had a right to remain under EU law.

In a number of judgments, most notably in the dicta of Laws LJ, the courts have entertained the possibility of such categories not being "hermetically sealed" 81 and have instead advocated an approach more broadly based on proportionality. In order for the deviation from the policy which created the legitimate expectation to be lawful, it would have to be "a proportionate response... having regard to a legitimate aim pursued by the public body in the public interest". ${ }^{82}$ This suggests that in determining whether the legitimate substantive expectations of EU citizens would be violated the court would not be limited to considering the scope of who was affected and whether the Government action took the form of an individual representation or a broader policy change.

Applying proportionality review, it seems likely that a court would find that the objective of changing immigration policy is both sufficiently important to justify limiting the rights of EU citizens, and also rationally connected to the objective of withdrawing from the European Union. A court could find, however, that if the Government were to renege upon the residence rights of EU citizens who are already resident in the United Kingdom then this would go beyond what is necessary to achieve the legitimate objective of withdrawal and the interconnected policy objective of re-asserting national immigration measures. On the other hand, it also seems possible that a court would find that the overriding public interest of leaving the European Union to enact the result of the referendum would be found to outweigh the interest of Union citizens in remaining, not least with respect to the doctrine of deference by the judiciary to political decision makers. In contrast to the necessarily unpredictable results of individual applications for judicial review, the clear promulgation or amendment of national law would provide more certainty for affected citizen. Legislative solutions also have the legitimising aspect of being promulgated by directly elected representatives in the national legislatures, rather than arising through the adjudicative functions of judicial actors.

\section{Legislative measures}

The practical advantage of legislation at the level of the state is that the problem of reciprocity discussed in the previous section is avoided; within the jurisdiction of the state such legislation is constrained only by compliance with the requirements of the internal constitutional order. However, the disadvantage of this is that such measures will only be promulgated if there is sufficient political will to address the rights of citizens. Furthermore, although such measures would provide assurances to citizens regarding immediate positive rights in the country of residence, they could not guarantee the continued application of the transnational rights to free movement and establishment in other countries that the harmonised Union legal order guarantees.

Derrick Wyatt, in his aforementioned contribution, rejects the applicability of legitimate expectations to a hypothetical Act of Parliament that contravenes the rights of EU citizens in the United Kingdom. However, he suggests that in practice the United Kingdom and EU Member States will adopt domestic

\footnotetext{
79 ibid.

80 Associated Provincial Pictures House Ltd v Wednesbury Corp [1948] 1 KB 223 [1947] 2 All ER 680, 230.

$81 R$ v. Secretary of State for Education and Employment, ex parte Begbie [2000] 1 WLR 1115 (AC) 1130 (Laws LJ).

${ }^{82} R$. (on the application of Nadarajah) $v$ Secretary of State for the Home Department [2005] EWCA Civ 1363, [68] (Laws LJ).
} 
legislation to vindicate acquired rights. ${ }^{83}$ The door to the adoption or retention of UK legislation to guarantee rights that have their source in EU law has been opened by the announcement by the Conservative Party of a 'Great Repeal Bill'. This would repeal the European Communities Act 1972 whilst simultaneously incorporating rights deriving from EU law into domestic legislation, giving the discretion to Parliament to decide which law they wish to retain, amend, or repeal. ${ }^{84}$

Accordingly, this parliamentary process could be used to ensure the protection for EU citizens of rights that before withdrawal derived from Union law. At present, the statutory system is that EU citizens are exempted from the ambit of the Immigration Act 1988. ${ }^{85}$ Therefore, a method that could protect the rights of Union citizens to remain in the United Kingdom would be to amend this Act to retain this exemption for any individuals who were entitled by virtue of a formerly enforceable Union right at the time that they entered the country. This would include within its ambit reliance on the Immigration (European Economic Area) Regulations 2006, which implement the conditions for residence of the 2004 Citizens Directive.

Although this would provide guarantees for European individuals who have already been exercising their Union rights to reside in the United Kingdom, the removal of the United Kingdom from the territory of the European Union would prevent the opportunity for future generations of EU citizens to pursue their life plans within the space of the United Kingdom with the protection of EU law. They would be subjected to the stringent requirements of the UK's immigration regime: this includes the need to fulfill the requirements for entry as a visitor to the UK for short visits, including funds, intention to return, and lack of intention to work, and the application of the "tiers" system of the immigration acts to those who come to work, in addition to EU students who will have to obtain a student visa and will not be eligible for home fees or loans. ${ }^{86}$ For this reason, as mentioned previously, the more holistic outcome for EU citizens would be the establishment of an international treaty regime, such as through the EEA agreement, which would ensure access to the United Kingdom and its social system for future generations, and judicial oversight over these rights by both the EFTA court and the Court of Justice of the European Union.

For UK citizens in Union territory, although there would be internal EU competence to legislate for movement and residence of British citizens,${ }^{87}$ initially unilateral action would also be left in the hands of individual Member States. Therefore, the above analysis of how EU citizens in the United Kingdom could be protected can be applied mutatis mutandis to the national immigration law of the 27 Member States, with respect to the different manners in which their constitutional orders implement the norms of Union law. However, in the absence of a uniform and binding Union position, the former Union rights of UK citizens would be left to the legislative discretion of each individual Member State, subject to

83 " $[\mathrm{T}]$ here are no limits on the authority of Parliament to change the law, and the powers of Parliament are not limited by any doctrine of legitimate expectation. But the handling of rights acquired under EU law prior to withdrawal would be likely to be dealt with in the withdrawal agreement, and lead to legislation in the UK which mirrored reciprocal legislation at EU level applicable in other Member States". European Union Committee, The Process of withdrawing from the European Union, Written evidence - Professor Derrick Wyatt QC, para 13. <http://data.parliament.uk /writtenevidence/committeeevidence.svc/evidencedocument/european-union-committee/the-process-of-leaving-theeu/written/32079.html> accessed 27 August 2016.

84 For a more detailed discussion of the legal implications of the Great Repeal Bill, see Oliver Garner, 'May's March Towards Brexit: Some Comments on the Potential Legal Implications of the UK's 'Great Repeal Bill' (European Law Blog, 10 October 2016) < http://europeanlawblog.eu/?tag=great-repeal-bill > accessed 9 November 2016.

85 Immigration Act 1988, s 7(1): “[a] person shall not under the principal Act require leave to enter or remain in the United Kingdom in any case in which he is entitled to do so by virtue of an enforceable Community [Union] right or of any provisions made under section 2(2) of the European Communities Act 1972".

86 For more extensive analysis, see Helena Wray, 'What Would Happen to EU Nationals Living or Planning to Visit or Live in the UK after a UK Exit from the EU?' (EU Law Analysis, 17 July 2014) <http://eulawanalysis.blogsp ot.com/2014/07/what-would-happen-to-eu-nationals.html> accessed 4 April 2016.

87 For discussion of the EU's competence to legislate on this issue see the next section of the paper. 
their obligations under Union legislation regulating the rights of Third Country Nationals ${ }^{88}$ in their territory. Furthermore, and crucially, even if the state in which a UK citizen is currently residing did decide to enact protective domestic measures, these would only be effective within this territory. Therefore, measures by one Member State could not uphold rights of free movement into other states, nor the rights of residence and access to social benefits in any of the other 26 Member States. This is particularly salient if protection is predicated on length of residence within the country. However, there is of course one unilateral national measure which would guarantee UK citizens the holistic guarantees to pursue their life plans across the territory of the European Union. This is the granting of nationality of a Member State, thus reactivating the condition in Article 20(1) for citizenship of the Union. The granting of citizenship of the United Kingdom to resident EU citizens would also ostensibly provide comprehensive redress to the consequences of fragmentation for these individuals.

\section{Granting national citizenship}

Acquiring UK citizenship via naturalisation would provide an effective solution for EU citizens living in the United Kingdom, provided they can retain their citizenship of their Member State and thus their EU citizenship. This would allow them all the benefits that a UK national enjoys, including permanent rights to residence and access to social benefits, in addition to remaining within the ambit of Union law and specifically the Citizens Directive if they travel to an EU Member State. Indeed, the prospect of a leave vote in the period leading up to the referendum prompted a rise in such applications. ${ }^{89}$ However, dual nationality is not allowed by every Member State: for example Austrian citizens automatically lose citizenship if another citizenship is acquired voluntarily, ${ }^{90}$ and de jure the same occurs in the Netherlands, subject to certain exceptions. ${ }^{91}$ Additionally, this is not an option available to EU citizens who have only recently emigrated to the United Kingdom, or who only reside in the United Kingdom seasonally or irregularly, as an explicit requirement of naturalisation is living in the UK for at least 5 years before the date of application, not having spent more than 450 days outside the UK during those 5 years, and not having spent more than 90 days outside the UK in the last 12 months. ${ }^{92}$ The last two requirements in particular make the option of attaining UK citizenship difficult for highly mobile EU citizens, who may easily spend more than 90 days in either their country of birth or other Member States. In effect, this makes citizenship available only to the first category of EU citizens discussed above who are permanently settled in another Member State and only minimally mobile in exercising their EU rights.

For UK citizens in an EU Member State, the stakes are - at least quantitatively - higher; becoming a citizen of one Member State allows access to the community space of all 27 Member States. There have already been calls from the German Green party to fast-track citizenship for UK nationals, ${ }^{93}$ in addition to similar suggestions by the Italian Prime Minister Matteo Renzi for UK nationals studying in Italian

88 See legislation concluded under TFEU, art.79.

89 Alan Travis, 'UK Passport Applications from EU Nationals Rose 14\% before Referendum' (The Guardian, 25 August 2016) <https://www.theguardian.com/world/2016/aug/25/net-migration-to-uk-fell-to-327000-in-past-year-figures-show> accessed 29 August 2016.

90 The Austrian Foreign Ministry, 'Austrian Citizenship' <https://www.bmeia.gv.at/reise-aufenthalt/leben-im-ausland/> accessed 27 August 2016.

91 Government of the Netherlands, 'Losing Dutch Nationality' <https:/www.government.nl/topics/dutchnationality/contents/loss-of-dutch-nationality> accessed 27 August 2016.

92 Government of the United Kingdom, 'Become a British citizen' < https://www.gov.uk/becoming-a-british-citizen/check-ifyou-can-apply> accessed 27 August 2016.

93 Kate Connolly, 'Give Britons Fast-Track Citizenship, Says Germany’s Green Party' (The Guardian ,1 August 2016) <https://www.theguardian.com/world/2016/aug/01/give-britons-fast-track-citizenship-says-germanys-green-party> accessed 27 August 2016. 
universities. ${ }^{94}$ However, regardless of how likely such a solution is in practice, there are other problems with relying on Member States granting citizenship to UK nationals. First, there are differing legal requirements for naturalisation and levels of political receptiveness in the other 27 Member States; this means that there would be no uniform guarantees for every UK citizen in European Union territory that they could be granted citizenship. Secondly, there is the issue that acquiring the nationality of another country requires a strong degree of connection that a UK national may not sufficiently feel for their country of residence. This undermines the added benefit of the EU legal order and EU citizenship of emancipating the individual from the nation state $;{ }^{95}$ contrary to this idea, in order to retain the supranational benefits of EU citizenship, an individual would be required to reintegrate themselves into a particular national polity. Furthermore, naturalisation into another polity would be a disproportionate solution to the specific nature of the problem of upholding the rights and status provided by Union law. ${ }^{96}$ Therefore, in the absence of fast-tracking, the requirements for attaining citizenship in many European countries means that it is an administratively and psychologically burdensome method of preserving one's status as an EU citizen.

Finally, a Member State may not feel they have sufficient resources to support these new citizens; this may be particularly true in countries such as Spain in which the majority of United Kingdom ex-patriates in Europe reside. Granting national citizenship means that individuals will not need to fulfil the conditions of the Citizens Directive in order to access certain social benefits, thus potentially placing more stress on the national welfare system. In summary, national measures conferring citizenship to those individuals who are most integrated into their state of residence will provide a comprehensive solution to the problem of de-integration for such individuals. However, regarding UK citizens residing in continental Europe, legal measures at the Union level would be necessary to ensure the most widely applicable protection.

\section{European Union law measures}

\section{Judicial measures on the basis of Rottman}

Before considering potential Union legislation, I will briefly consider the possibility of the Court of Justice protecting the substance of citizenship. In Rottman, the Court of Justice found that being deprived of citizenship of a Member State is a matter for judicial review by the Court of Justice because it deprives the individual of their EU law rights; however, the Court will only prohibit such a measure if it is not proportionate. ${ }^{97}$ Gareth Davies has ruled out the possibility of Brexit being blocked by the Court of Justice of the European Union through the extension the Rottman doctrine to an Article 50 withdrawal. He provides three arguments: that once the UK ceases to be a Member State the deprivation of EU law rights of its citizens would no longer be a matter for EU law; that Rottman only regulates at the individual level whereas Article 50 regulates at the Member State level; and that it is highly unlikely that the Court would find the loss of EU citizenship through a negotiated agreement under Article 50 to be disproportionate. ${ }^{98}$ Although Davies limits its arguments to why Rottman could not be used to block

\footnotetext{
94 Insider Newsdesk, 'Italy Wants to Give Citizenship to UK Students' (The Italian Insider, 27 June 2016) <http://www.italianinsider.it/?q=node/3999> accessed 27 August 2016.

95 See Floris De Witte, 'Emancipation Through EU Law?' (n.2) above, and also 'Freedom of movement under attack: is it worth defending as the core of EU citizenship?' (EUDO Citizenship Forum Blogs) < http://eudocitizenship.eu/commentaries/citizenship-forum/citizenship-forum-cat> accessed 9 May 2016.

96 I thank Neil Walker for this specific observation.

97 Case C-135-08 Janko Rottman v Freistaat Bayern [2010] I-01449.

98 Gareth Davies, 'Union Citizenship - Still Europeans' Destiny after Brexit?' (European Law Blog, 7 July 2016) $<$ http://europeanlawblog.eu/?p=3267> accessed 29 August 2016.
} 
Brexit, I would argue that the same considerations apply in determining the success of an application to the Court to uphold the status of EU citizenship for a UK national following withdrawal.

There are some parallels to the operation of substantive legitimate expectations in English law discussed above: the Brexit situation can be compared to the first Coughlan category of policy changes at the macro-political level as opposed to measures in the third category which affect only select individuals. One could envisage a situation in which the Court might subject a UK Government decision to proportionality review on the application of affected individuals - for example if the option to repeal the ECA 1972 were taken without triggering Article 50, thus failing to follow the legitimate Union legal procedure for nationals of a Member State to lose their EU citizenship. However, assuming that the procedure of Article 50 is followed, it seems unlikely that the Court would find a violation. In addition to the predicted reticence of the Court to intervene in such a charged political issue, from the normative point of view of respecting democratic decisions by the Member States ${ }^{99}$ it would be highly undesirable for the Court of Justice to try to enact legal protection of citizenship 'through the backdoor'. This argument is that this would be in clear contradiction of the results of a national democratic procedure for triggering withdrawal that was conducted in accordance with the explicit primary law of the Treaties. Instead, if such a watershed moment for the scope of the status of citizenship is to occur then it should be enacted through the political process of the creation of secondary and/or primary Union law.

\section{Union legislative measures}

Picking up again on the theme of reciprocity, it is a point of withdrawal negotiation whether measures promulgated by the European Union regarding United Kingdom citizens would legally require the same obligations to be promulgated by the United Kingdom regarding EU citizens. Of course, the question of whether politically the Member States would agree to such measures without reciprocal guarantees for their own citizens in the United Kingdom is another matter. Regardless, in terms of the Union's legal order, the constitutional structure of the Treaties takes precedence for the purpose of the creation and enforcement of Union law obligations. ${ }^{100}$ Although the issue of the capacity of the European Union to create an asymmetry between the rights of individuals and the obligations of their state of origin should be addressed in greater detail in the future, for the purposes of the analysis here I proceed on the assumption that the Union would not be legally precluded from adopting measures regardless of whether or not the United Kingdom chooses to reciprocate.

Following withdrawal, UK nationals would ostensibly fall within the category of 'Third-Country Nationals'. The Union would consequently have competence to legislate on their position under Article 79 TFEU. ${ }^{101}$ Article 79(2) outlines that the European Parliament and Council may adopt measures concerning the conditions of entry and residence and standards on the issue by Member States of long term visas and residence permits for Third-Country Nationals, and the definition of the rights of ThirdCountry Nationals residing legally in a Member State, including conditions governing freedom of

99 For more on the argument in the context of the Union respecting democratic decisions of secession in the Member States, see Dimitry Kochenov and Martijn van den Brink, 'Secession from EU Member States: The Imperative of Union's Neutrality’ (2016), University of Edinburgh School of Law, Research Paper Series No 2016/06; Europa Working Paper 2016/04.

100 See Bruno de Witte, 'European Union Law: How Autonomous is its Legal Order?’ Z öffentl Recht (2010), 152: “The Court of Justice affirmed, already quite early in the history of Community law, that the general international rule allowing states to retaliate in the event of non-compliance by other parties to the same treaty (inadiplementi non est adimplendum) did not apply in the context of EC law". This comment is based on the decision in Joined Cases 90/63 and 91/63, Commission v Luxembourg and Belgium (1964) ECR - special English edition. Of particular relevance is the Court's statement, echoing Van Gend en Loos, that "the Treaty is not limited to creating reciprocal obligations between the different natural and legal persons to whom it is applicable, but establishes a new legal order which governs the powers, rights and obligations of the said persons".

101 TFEU, art.79. 
movement and of residence in other Member States. ${ }^{102}$ Legislation under this Article could co-ordinate with the rights agreed upon in a withdrawal or future relations treaty, and serve to incorporate the terms into the internal law of the Union. UK nationals would also benefit from the protection of rights in preexisting legislation concluded under this treaty base, including the conditional right of entrance and residence for immediate family members, ${ }^{103}$ the conditional right to acquire long-term resident status after five years of continuous legal residence, ${ }^{104}$ and the conditional right of third country students to enter and reside in a Member State for more than 90 days. ${ }^{105}$

However, despite provision for such disparate substantive rights, Article 79(5) outlines that the article does not affect the right of Member States to determine volumes of admission of third-country nationals coming from third countries. Therefore, similarly to unilateral measures by Member States, it appears that legislation under Article 79 could define and crystallise the rights of UK citizens who already reside legally in other Member States, but it would not guarantee unfettered access to the territory of Member States for future generations without being subjected to national immigration law. This stands in contrast to the citizenship right of Article 21(1) TFEU that outlines that every citizen of the Union shall have the right to move and reside freely within the territory of the Member States, subject only to the limitations and conditions of Union law, as opposed to national immigration law. As a final point, it should also be noted that such legislation concluded under Article 79 would not have effect for UK citizens in Denmark due to the Member State's opt-out from AFSJ measures, ${ }^{106}$ and that the Republic of Ireland would have the choice whether or not to opt-in to the measures. ${ }^{107}$

Another potential legal basis could be Article 114 TFEU which allows residual competence to adopt measures which have as their object the establishment and functioning of the internal market. Article 114(1) TFEU outlines that the provision applies for the achievement of the objectives set out in Article 26 TFEU. Preserving the citizenship rights of UK nationals can be argued to fall within this because Article 26(1) outlines that the Union shall adopt measures to establish or ensure the functioning of the internal market, and paragraph 2 details that the internal market comprises an area without internal frontiers in which, inter alia, the free movement of persons is ensured. British American Tobacco ${ }^{108}$ outlines that resort to Article 114 is justified when the provision genuinely has its object the improvement of the conditions for the functioning of the internal market: therefore with regard to the rights of UK nationals to move freely and work in the territory of the Member States, the argument could be that the measure genuinely has its object the preservation of the functioning of the internal market and to prevent distortions caused by a lack of harmonisation with regard to different Member States adopting different rules with regard to the rights of UK nationals. However, it is doubtful whether a measure promulgated under Article 114 TFEU to protect non-economically active UK nationals would pass the American Tobacco test of genuinely having the object of improving the functioning of the internal market. Therefore, this internal market focus would mean that measures passed under Article 114 TFEU would be limited to the economically active UK nationals who fall under the citizenship sub-

\footnotetext{
102 TFEU, art 79(1)(a),(b).

103 Council Directive 2003/86/EC of 22 September 2003 on the right to family reunification [2003] OJ L 251/12.

104 Council Directive 2003/109/EC of 25 November 2003 concerning the status of third-country nationals who are long-term residents [2003] OJ L 16/44.

105 Directive (EU) 2016/801 of the European Parliament and of the Council on the conditions of entry and residence of thirdcountry nationals for the purposes of research, studies, training, voluntary service, pupil exchange schemes or educational projects and au pairing [2016] OJ L 132/21.

106 TFEU, protocol (No 22) on the position of Denmark,

107 TFEU, protocol (No 21) on the position of the United Kingdom and Ireland in respect of the Area of Freedom, Security and Justice. However, it should be noted that not only is it likely that Ireland would opt-in to such measures due to its close relationship with the UK, but that also the Common Travel Area between the two countries is likely to be maintained thus rendering some of the protection under hypothetical TCN legislation nugatory.

108 Case C-491/01 British American Tobacco (Investments) and Imperial Tobacco [2002] ECR I-11453.
} 
category of 'workers'. Similarly to the EEA solution discussed above, it would uphold the preMaastricht Article 49 EU worker paradigm, rather than the post-Maastricht Article 20 EU citizen paradigm. ${ }^{109}$

A further option is the creation of legislation under the 'flexibility clause' of Article 352 TFEU. This could allow for a more holistic preservation of the status of Union citizenship for UK nationals living within the European Union. The argument could be made that it is necessary in order to attain, or more accurately to preserve, the objective in the treaty of ever closer union among the people of Europe ${ }^{110}$ and non-discrimination on the basis of nationality ${ }^{111}$ that nationals of a Member State which withdraws from the Union should be able to preserve their citizenship rights. I would argue that the wide scope of competence afforded by this legal base means that it is the only viable option for an extensive excitizenship regime if the Union decided to follow the route of secondary legislation. As discussed below, however, such a legislative intention may be found by the Court of Justice to be too precise to fall under the flexibility clause. Furthermore, the unanimity requirement of Article 352 increases the practical barrier to such legislation being passed as opposed to the treaty bases which only require Qualified Majority Voting.

Providing such legislation were found to have a sufficient legal base, the secondary law could operate analogously to Directive 2004/38 as an 'ex-Citizens Directive' that would mirror the substantive content of the legislation for those UK citizens who wish to opt-in to the regime. Although apparently novel, at least a partial precedent for the retention of legal rights following secession from a legal system is provided by the status of Irish citizens in the United Kingdom, who benefit from a Common Travel Area and voting rights in British elections and referenda. ${ }^{112}$ Just as Irish citizens in the UK are not to be considered "aliens" or from a "foreign country" due to historical connections, UK nationals in the European Union could be considered not to be Third-Country Nationals due to their historical status as EU citizens. Such an understanding, if enshrined legally as it is in the United Kingdom, ${ }^{113}$ could ensure UK nationals remain within the jurisdiction of 'internal' Union competences.

A system could be set up by which a Member State would operate as a 'legal guardian' of an ex-EU citizen so that they may avail themselves of the enforcement architecture of EU law through the national courts of the guardian Member State. The substantive focus of this would be ensuring the preservation of non-discrimination on the basis of nationality for UK nationals throughout the Union's territory. The procedural focus would be the Member States obligation to that individual to provide effective judicial protection in accordance with Article 47 of the Charter of Fundamental Rights. Member States could be incentivised to provide such a status through the creation of a guardianship 'tax' or similar remuneration. ${ }^{114}$

The advantage of such a regime for states in comparison to granting national citizenship to UK nationals is that it would limit individual access to the social benefits system of the Member State to the conditions specified in the Citizens Directive. For the individual, it would allow them to continue exercising their EU citizenship rights without the need to take the demanding steps of integrating fully into the national polity of their state of residence. Furthermore, this could also be advantageous for the Member State

\footnotetext{
109 For more on this distinction, see Päivi Johanna Neuvonen, Equal Citizenship and Its Limits in EU Law: We The Burden? (Bloomsbury Publishing 2016).

110 TEU, art 1.

111 TFEU, art 18.

112 See Melanie Gower, 'The Common Travel Area, and the special status of Irish nationals in UK law' (House of Commons Briefing Paper Number 7661, 15 July 2016) <http://researchbriefings.parliament.uk/ResearchBriefing/Summary/CBP7661\#fullreport> accessed 27 August 2016.

113 See the Ireland Act 1949, s 2; the British Nationality Act 1981, s 50(1).

114 The socio-economic details of how such a regime would work in practice, and its interaction with Member State social welfare mechanisms, requires further future development.
} 
which has withdrawn; although it may be argued that such a bifurcation of the polity into non-EU citizens and EU citizens could promote inequality, the truth is that the referendum result has already exposed such a cleavage. By enabling those who previously exercised their EU citizenship rights to preserve this status without needing to naturalise as a citizen of another Member State, this could preserve the connection of these UK citizens to their state, rather than prompting a psychological exodus to the polity of an EU Member State. However, an important critique of such proposals to maintain the EU law rights and status of the nationals of a withdrawing Member State concerns the boundaries of inclusion: would such an option to 'opt-in' only extend to present UK citizens, or also to future generations? ${ }^{115}$ For this reason, I would argue that the 'ex-Citizens Directive' could and should operate only as a transitional arrangement before the implementation of a comprehensive reconfiguration of $\mathrm{EU}$ citizenship.

Although I would argue that this proposal fulfils the standard of comprehensive protection (at least for those UK citizens presently affected by fragmentation), in terms of the other criterion of assessment such a suggestion may not be practically viable. These measures would require a grand confluence of political will amongst the Member States, in accordance with the Qualified Majority Voting system, to protect UK nationals. For a measure under Article 352 the bar is set even higher due to the requirement of unanimity in the Council. The question arises: why should a Member State vote to protect the rights of UK nationals on Union territory if the United Kingdom is unwilling to protect the rights of Member State nationals? Picking up on the discussion of legal bases above, even if the legislation were passed the privileged applicants outlined in Article 263 TFEU $^{116}$ may apply for judicial review on the grounds of lack of competence. Member State national parliaments may also argue that such provisions do not comply with subsidiarity following the Commission's obligation to inform in accordance with Article 352(3). Parliaments may show the 'yellow card' of Article 3 of Protocol (No 1) TFEU due to the consideration that legislating on the rights of third country nationals in their territory does not require Union coordination, and should be dealt with exclusively through the national measures discussed above.

Perhaps the most pertinent practical barrier would be the argument that the use of Article 352 to create such an extensive ex-citizenship regime does not have a sufficient connection to the objectives of the treaty. However, on a more optimistic note, if the political will among the Member States was unanimous then a treaty revision could be made to provide the legal basis for such measures to preserve the citizenship rights of ex-Member State nationals.

\section{Primary law revision: Reform of citizenship of the European Union}

The MEP Charles Goerens has proposed an amendment to a European Parliament Committee on Constitutional Affairs draft report in order to address the loss of EU citizenship by nationals of former Member States. He advocates the insertion of a "European associate citizenship for those who feel and wish to be part of the European project" which would guarantee their citizenship rights of movement, residence, access to social benefits, and political representation. ${ }^{117}$ The incremental development of Union citizenship by creating such an 'associate citizenship' to preserve the rights of ex-Member State nationals would represent a watershed moment: it would be the first instance of the disconnection of Union citizenship from nationality of a Member State. ${ }^{118}$ I would argue that such a disconnection would provide the ultimate comprehensive protection of Union rights and the status of citizenship by insulating these benefits from the majority decisions taken through Member State democratic procedures. This

\footnotetext{
115 I thank the participants at the Europa Research Group meeting on 25 October 2016 for this astute observation.

116 TFEU art.263 outlines that these applicants are the Member States, the European Parliament, the Council, or Commision. The most likely applicant would be a 'defeated' Member State if a legal base were pursued that utilises the QMV procedure.

117 See European Parliament Draft Report (n.1 above).

118 For tentative moment towards this idea, see Mark Dawson and Daniel Augenstein, 'After Brexit: Time for a further Decoupling of European and National Citizenship?' (Verfassungblog, 14 July 2016) <http://verfassungsblog.de/brexitdecoupling-european-national-citizenship/> accessed 30 September 2016.
} 
may be seen as a step towards the 'destiny' predicted by the Court of Justice of Union citizenship becoming the fundamental status of all nationals of the Member States.

The fallout from the cleavages caused by the UK referendum could be a harbinger for a more differentiated development of EU citizenship. This would involve a reframing of the various calls for a "core Europe" ${ }^{119}$ composed of a vanguard of states who push forward with integration. Instead of the subjects being states, the subjects would be citizens who are most receptive to integration due to their reliance on the guarantees provided by EU law to vindicate their pursuit of fulfillment. This would go further than Goerens' proposals for an associate citizenship limited to nationals of a former Member State. Instead, all Member State and Third-Country Nationals who 'feel and wish to be part of the European project' would be enabled to acquire the fundamental state of citizenship. With regard to Third-Country Nationals, this could be achieved through amendment of Article 20 TFEU to reframe the conditions for acquiring EU citizenship; requirements similar to the naturalisation requirements for a nation state could be instituted, such as period of residence on the Union's territory. ${ }^{120}$ In tandem with such incremental steps, however, such a constitutional moment would most likely require a corresponding documentary re-statement of EU citizenship to legitimise the creation of the core Union citizenry.

Returning to Habermas' dual-constituent thesis, this constitution of a core citizenry would emancipate the role of 'citizen of the Union' from being predicated on also being a member of a 'European people'. Such a subject-shift is more reflective of the true attitudinal differences to European integration in Member States; there are no Member States whose polities are completely committed to European integration, ${ }^{121}$ instead there are attitudinal differences based on differences of mobility and engagement with European integration within societies. The development of such a floating polity through the creation of an option to choose to become a European citizen for current Member State nationals, and through the option to 'naturalise' for Third Country Nationals, would be the ultimate vindication of the direct link between European individuals and the European Union that was introduced by the creation of EU citizenship at Maastricht.

This would accordingly insulate European individuals' status as European citizens from the fragmentation arising from decisions made by their Member State. Away from the withdrawal context, such a disconnection could address the somewhat precarious and shifting status of Third Country Nationals in Union law ${ }^{122}$ by allowing them to attain full citizenship. Such a truly constitutive moment would also avoid the imposition of the status of European citizens on those Member State nationals who do not engage with integration for their own fulfillment. Crucially, although these individuals may choose not to take the option of becoming an EU citizen - as evidenced by the anti-EU sentiments expressed in the UK referendum - the door should in principle always be open to all Member State nationals to make the choice in the future. An initial challenge that this proposal would remove the democratic rights of these individuals who do not choose to become citizens of the Union can be addressed. ${ }^{123}$ The dual-constituent role of these individuals as members of a European people would still

119 See, inter alia, Jean-Claude Piris, The Future of Europe: Towards a Two-Speed EU? (Cambridge University Press 2012); Jürgen Habermas 'Core Europe To The Rescue: A Conversation With Jürgen Habermas About Brexit And The EU Crisis' (Social Europe, 12 July 2016) <https://www.socialeurope.eu/2016/07/core-europe-to-the-rescue/> accessed 27 August 2016; Daniel Seikel, 'The European Union In Crisis - Is Flexible Integration The Way Forward?' (Social Europe, 22 July 2016) <https://www.socialeurope.eu/2016/07/european-union-crisis-flexible-integration-way-forward/> accessed 29 August 2016.

120 For discussion of the shift from 'Member State territory' to 'Union territory', see Loïc Azoulai, “Transfiguring European citizenship: from Member State territory to Union Territory" in Dimitry Kochenov (ed.) EU Citizenship and Federalism: The Role of Rights (Cambridge University Press 2017).

121 See European Commission, 'Public Opinion in the European Union' (Standard Eurobarometer 83, Spring 2015)< http://ec.europa.eu/public_opinion/archives/eb/eb83/eb83_publ_en.pdf> accessed 27 August 2016.

122 See, inter alia, Ruiz Zambrano (n.61).

${ }^{123}$ I thank Martijn van den Brink for this powerful critique in written comments. My brief response to these challenges here does not do justice to the scale of the theoretical puzzle, and will require detailed future development. 
be vindicated through representation by national ministers in the Council during the creation of legislation, even if they were not represented directly in the European Parliament. Of course, this idea requires extensive future development, including practical considerations such as determining to whom Union law would apply in a differentiated Union, and the role of representation in the law-creating bodies. However, the prospect of the mass deprivation of citizenship rights for an entire Member State polity as the consequence of the United Kingdom's withdrawal from the European Union has perhaps opened the door to consideration of such radical future developments.

In summary, there are options at numerous levels to protect the rights of European citizens affected by the decision of the United Kingdom to withdraw from the European Union. The creation of international treaty rights would provide transnationally applicable law for individuals within the territory of the state parties subject to the agreement. However, this does not preserve the status of citizenship from which such rights derive in the same way that they are provided for in the legal order of the European Union. The United Kingdom's accession to the EEA would be the best solution for EU citizens in the UK whose EU citizenship is unaffected by Brexit, but it would not preserve the citizenship rights of UK nationals in Europe. Unilateral national measures by Member States may provide the most practicable and speedy transitional protection of status, but they can only protect individual rights in a piecemeal fashion, and are not subject to uniform application throughout the territory of the Union nor supranational judicial oversight. Therefore, for EU citizens in the territory of the United Kingdom, the most desirable solution would be a combination of international and domestic legal measures - including legislation or the ability to naturalise - vindicating their acquired rights in the United Kingdom's territory. For UK nationals, the creation of Union law to preserve the status of citizenship for UK nationals, and potential reforms to the substance of citizenship to insulate this status from future developments, would provide the most holistic and comprehensive protection. After Brexit, such a constitution of a core European citizenry would insulate the rights and status of all EU citizens from future fragmentation.

\section{Conclusion: A phoenix moment for European integration?}

The United Kingdom vote to leave the European Union is a seismic event because for the first time in the history of European integration an entire Member State polity may lose the legal rights that they derive from their status as European Union citizens. Furthermore, for the first time in the history of the Union's expansion from 6 to 28 Member States, the territory of the legal order may contract and Union law norms may be de-applied in the national legal order of the United Kingdom. The scope of European integration will be fragmented.

This paper has sought to provide a broad overview of what legal solutions there may be for preserving the individual rights of affected EU and UK citizens and the status of citizenship. Despite the upheaval and uncertainty of Brexit, the potential solutions point towards how this fragmentation could be a watershed moment for the development of European citizenship. As Gareth Davies has argued, ${ }^{124}$ the outcry of the remain supporters shows the success of the European identity-building project; furthermore, the vote has caused citizens in other Member States to reconsider exactly what the value of European integration is for them. ${ }^{125}$ Davies states that a new generation of Europeans was born on the week of the vote; the years after Brexit may see this new generation of European citizens and citizenship grow to maturity. From the ashes of fragmentation in the scope of the legal order, the phoenix of a true constitutional polity may arise.

124 Gareth Davies, ‘What Does It All Mean?’ (2016) 17 GLJ Brexit supplement 7, 9.

125 Aamna Mohdin, 'After the Brexit Vote, People in Europe Are Suddenly Feeling a Lot More European' (Quartz, July 6 2016) <http://qz.com/723813/after-brexit-people-in-europe-are-suddenly-feeling-a-lot-more-european/> accessed 30 August 2016. 

